\title{
STUDI EKSPERIMENTAL LAJU KOROSI PADA KAPAL BAJA
}

\author{
Sonja Treisje A. Lekatompessy ${ }^{1}$, Gerard R. Latuhihin ${ }^{2}$ \\ Email: 'Sonja_lekatompessy@yahoo.com \\ Fakultas Teknik Universitas Pattimura Jl. Ir. Putuhena Poka, Ambon
}

\begin{abstract}
ABSTRAK
Korosi merupakan perkaratan, sedangkan perkaratan terjadi karena adanya reaksi reduksi- oksidasi. Peristiwa ini biasa terjadi di dalam pelat kapal sebagai akibat interaksi dengan lingkungan sekitarnya. Dalam penulisan ini disajikan hasil penelitian tentang analisa ketahanan korosi pada pelat baja yang biasa dipakai sebagai material kapal dengan mengamati perubahan massa yang hilang. Pengendalian korosi pelat baja dilakukan dengan melapiskan cat ke dalam permukaan baja selanjutnya ditempatkan di dalam lingkungan korosif. Penentuan suhu serta waktu tunggu pelapisan cat pada kapal merupakan fokus penelitan ini, karena produk cat yang seringkali dipakai di dok Perikani memiliki ketentuannya sendiri. Kemudian analisa ketahanan korosif plat baja dengan suhu dan waktu tunggu yang berbeda-beda meliputi beberapa pengujian di dalam laboratorium antara lain kekuatan dan daya lekat. Produk cat yang diambil ialah Internasional, sedangkan variable suhu dan waktu tunggu pengecatan masing-masing 2 yang selanjutnya disimulasikan pada pelat baja ST-40 dengan ketebalan $8 \mathrm{~mm}$. Hasil penelitian ini menunjukkan bahwa laju korosi pada plat baja yang diaplikasikan dengan suhu rendah dan waktu sedikit akan memiliki laju korosi yang cukup tinggi.
\end{abstract}

Kata Kunci: korosi logam, cat

\section{PENDAHULUAN}

Dalam dunia industri perkapalan baja merupakan bahan yang sering kali digunakan sebagai komponen pelat utama baik lambung maupun konstruksi dari sebuah kapal. Dampak ancaman korosi cukup besar sehingga diperlukan beberapa cara untuk melindungi baja tersebut dari berbagai kerusakan yang mungkin terjadi dengan tujuan memperpanjang umur pakai material tersebut.

Ada beberapa prinsip pencegahan korosi yang telah berkembang. Pencegahan korosi pada baja yang cukup luas dikenal adalah dengan cara melapisi baja dengan lapisan penghalang (coatings). Coating biasanya dilakukan saat kapal baru selesai di buat maupun saat pengedokan/reparasi kapal. Permasalahan yang terjadi khususnya pada saat reparasi kapal dapat menghambat pekerjaan pada suatu galangan secara keseluruhan, oleh karena itu diperlukan pemecahan masalah pada tiap kasus yang terjadi pada dok tersebut. PT. Perikani Nusantara adalah salah satu perusahaan negara yang bergerak dibidang reparasi kapal.

Dewasa ini permasalahan yang berkaitan dengan pengecatan sering ditemukan di dok terkait. Permasalahan tersebut akan berpengaruh pada kegagalan pengecatan dan sangat berkaitan terhadap pengaruh laju korosi pada kapal.
Penentuan produk cat yang tepat dan tahan terhadap pengaruh lingkungan korosif bukanlah hal yang mudah, karena produk cat yang ada di pasaran saat ini, khususnya cat untuk kapal laut hanya diformulasikan untuk daerah tropis, komposisi dan karakteristiknya belum tentu sama. Merk cat yang biasa digunakan di dok ini merupakan cat kapal Internsdional. Merk cat tersebut memiliki beberapa kriteria saat pengecatan salah satunya suhu pada saat pengecatan haruslah $38^{\circ} \mathrm{C}$ serta waktu tunggu untuk pelapisan berikutnya ialah 4 jam, ditinjau dari kondisi lapangan suhu yang digunakan ratarata dibawah standar dikarenakan hujan serta mendung yang pada akhir-akhir ini sering terjadi. Dalam kondisi demikian karena perusahaan dituntut untuk mengejar waktu deadline maka seringkali mengabaikan suhu serta waktu yang menjadi standar peraturan dari merk cat tersebut. Untuk itu perlu diteliti performance dari cat tersebut jika dipaksakan dalam kondisi demikian, ataupun jika sesuai standar, dan merk cat lain tanpa standar, yang meliputi katahanan terhadap lingkungan asam, maupun kekuatan adhesi cat.

Sasaran utama penelitian ini adalah untuk mengetahui performance dari pengecatan yang menggunakan cat merk International serta standar suhu dan waktu international dengan pengecatan cat merk international yang tidak menggunakan 
standar suhu dan waktu international pada daerah bottom kapal. Tujuan dari penelitian ini ialah untuk mengetahui bagaimana laju korosi daerah bottom kapal dengan perlakuan pengecatan menggunakan cat merk international dan standar waktu serta suhunya sesuai dan tidak sesuai dengan standar pabrik international.

\section{KAJIAN TEORI DAN METODE}

Peristiwa korosi adalah perkaratan. Sedangkan perkaratan terjadi karena adanya reaksi reduksioksidasi. NACE (National Association of Corrosion Engineer) mendefinisikan korosi sebagai penurunan mutu suatu material (biasanya baja) atau sifat-sifatnya yang diakibatkan oleh reaksi dengan lingkungannya. Sedangkan Trethewey (1988) memberikan definisi korosi sebagai penurunan mutu baja akibat reaksi elektrokimia dengan lingkungannya [Korosi untuk Mahasiswa dan Rekayasawan ]. Secara prinsip bahwa fenomena korosi hanya akan terjadi jika memenuhi keempat faktor berikut [Organic Coating Technology]: Anoda, merupakan daerah baja yang mengalami korosi (teroksidasi) ; Katoda, merupakan daerah baja yang tidak terkorosi (tereduksi) ;Elektrolit, sebagai media penghantar listrik; Penghubung antara anoda dengan katoda (metallic path).

Pada dasarnya semua baja tidak stabil dan cenderung bereaksi dengan lingkungannya, dengan membentuk senyawa oksida atau karbonat yang bersifat stabil. Kecenderungan baja untuk melepaskan elektron pada saat terjadi proses reaksi elektro-kimia dalam membentuk korosi, menunjukkan sifat keaktifan dari baja yang bersangkutan. Reaksi reduksi oksidasi adalah jika ada reaktan yang melepas elektron (spesi ini mengalami reaksi oksidasi, zatnya sering disebut reduktor) dan menerima elektron (spesi ini mengalami reaksi reduksi, zatnya sering disebut oksidator) maka dikatakan reaksi reduksi oksidasi dapat berlangsung. Tingkat kemudahan/ kesulitan reaksi reduksi - oksidasi sangat tergantung pada kemudahan dari masing-masing reduktor untuk melepas elektronnya dan oksidator dalam menerima pasangan elektronnya. Sedangkan tingkat kemudahan/kesulitan reaksi reduksioksidasi dapat dilihat dari tingkat energi yang diperlukan untuk reaksi tersebut. Energi yang muncul dari reaksi ini dilambangkan sebagai Potensial Sel standar (E sell), yang secara matematik dapat dituliskan seperti berikut: $\mathrm{E}$ sell $=\mathrm{E}$ reduksi $-\mathrm{E}$ oksidasi atau
$\mathrm{E}$ sell $=\mathrm{E}$ kanan $-\mathrm{E}$ kiri.

Semakin besar harga E sell, berarti semakin mudah reaksi reduksi-oksidasi tersebut berlangsung, demikian juga sebaliknya, semakin kecil harga E sell semakin susah reaksi reduksioksidasi tersebut berlangsung.

Untuk memperlambat korosi, ada beberapa cara yang bisa ditempuh, yaitu: pelapisan logam, pengecatan, perlindungan katodik, dan memperkecil katalisator dalam sistem.

Pada dasarnya cat dapat dikelompokan sebagai [The Protective Action of Organic on Steel: A review ]: wahana (vehicle), terdiri dari pelarut dan resin cat, yaitu zat cair yang menjadikan cat memiliki fluiditas dan bila mengering atau menguap meninggalkan selaput kering yang padat (dry film); Pigmen yang tersuspensikan dalam wahana. Pigmen mengendalikan laju korosi atau laju difusi reaktan-reaktan pada selaput kering (dry film); Aditif yang mempercepat proses pengeringan atau memungkinkan lapisan cat kering lebih tahan terhadap lingkungan kerjanya.

Faktor Suhu dan Waktu pada pelapisan pengecatan berpengaruh terhadap proses pengeringan cat. Selain Selain sifat-sifat cat basah, perlu juga diketahui bagaimana cat tersebut dapat mengering sesuai dengan waktu dan kualitas yang dikehendaki

Rancangan dan prosedur penelitian yang dilakukan antara lain : mempersiapkan spesimen berupa pelat baja ST-40 tebal $8 \mathrm{~mm}$ berukuran $5 \times 8 \mathrm{~cm}$; cat yang digunakan pada bottom area, menggunakan cat merk Internasional. Proses pengecatan dilakukan sesuai prosedur, yaitu:

sebelum pengecatan dimulai terlebih dahulu dilakukan penyiapan permukaan yang bertujuan agar cat dapat menempel dengan baik pada permukaan baja. Pekerjaan persiapan ini meliputi pembersihan secara mekanis (pengamplasan) dan pencucian dengan detergen, yang bertujuan untuk menghilangkan debu, kotoran, minyak, lemak dan pengotor lainnya dari baja. Tahap pengecatan selanjutnya dilakukan dengan menggunakan metode penyemprotan bertekanan (air spraying) dengan peralatan utama hand air sprayer dan kompresor udara. Pengecatan dilakukan dengan tekanan sesuai dengan rekomendasi dari pabrik namun temperature divariasikan. Pada akhirnya ketebalan cat hasil pengecatan diukur dengan alat monimeter. Tiap spesimen diambil 8 titik pengukuran. Waktu tunggu pelapisan cat untuk 
masing-masing suhu: $24^{0} \mathrm{C}$ step I 1 jam step II 2 jam; $24^{0} \mathrm{C}$ step I 2 jam step II 4 jam; $31^{\circ} \mathrm{C}$ step I 1 jam step II 2 jam; $31^{\circ} \mathrm{C}$ step I 2 jam step II 4 jam.

Pengujian laju korosi dengan menggunakan $\mathrm{HCl}$ dan $\mathrm{NaCl}$. Berikut urutan dari metode yang akan digunakan: Pengujian korosi (Immersion Test) untuk spesimen yang dicat (coating) mengacu pada ASTM G31-72 (Practice for Laboratory Immersion Corrosion Testing of Metals). Metode ini biasa digunakan untuk mengetahui ketahanan material (pelapis) pada kondisi yang mirip dengan lingkungan sebenarnya yaitu ketahanan terhadap larutan asam dan garam. Larutan yang digunakan pada pengujian ini adalah asam khlorida $(\mathrm{HCl} 1,5 \mathrm{M})$. Sebelum pengujian ini, spesimen ditimbang dahulu untuk mengetahui berat awal sebelum pengujian. Spesimen ini ditimbang dengan menggunakan alat timbang elektronik. Dalam ASTM G31-72 dicantumkan dua harga volume larutan korosif persatuan luas spesimen yaitu 20 dan $40 \mathrm{ml} / \mathrm{cm} 2$. Volume yang dipilih adalah $20 \mathrm{ml} / \mathrm{cm} 2$. Pemilihan ini sematamata berdasarkan pertimbangan ekonomis. jadi dibutuhkan larutan sebanyak $500 \mathrm{ml}$. Durasi pengujian selama 2 minggu. Peralatan dan bahan yang digunakan pada pengujiaan penyemprotan garam antara lain: salt droplet cabinet, gun spray, kompresor, larutan garam $(\mathrm{NaCl})$ sebagai media korosi dan clarke's solution. Lama pengujian 4 minggu. Larutan garam dibuat dengan bahan berturut-turut adalah: 26,5 gram $\mathrm{NaCl} ; 2,4$ gram $\mathrm{MgCl} ; 3,3$ gram $\mathrm{MgSO} 4 ; 1,1$ gram $\mathrm{CaCl} 2 ; 0,73$ gram $\mathrm{KCl} ; 0,2$ gram $\mathrm{NaHCO}$; 0,28 gram $\mathrm{NaBr}$. Semua bahan ini dilarutkan dalam 1 (satu) liter aquades atau air suling. Sebelum pengujian ini, spesimen ditimbang dahulu untuk mengetahui berat awal sebelum pengujian. Spesimen ini ditimbang dengan menggunakan alat timbang elektronik.

Selanjutnya dilakukan pengujian daya lekat cat dengan menggunakan ujung pisau yang tajam, dibuat kotak-kotak kecil dengan panjang rusuk 1 $2 \mathrm{~mm}$ sebanyak 100 kotak. Tempelkan selotip yang daya lekatnya kuat pada kotak-kotak tersebut, kemudian sentakkan selotip tersebut dengan cepat. Dengan melihat berapa jumlah kotak yang rusak, maka didapat persentase untuk menilai daya lekat cat berdasarkan standar ASTM 3359-87. Menghitung laju korosi dapat ditentukan dengan menggunakan persamaan sebagai berikut:

$$
\mathrm{MPY}=\frac{534 . W}{D \cdot A \cdot T}
$$

$$
\begin{aligned}
\mathrm{mm} / \mathrm{yr}= & \frac{87.6 \cdot W}{D \cdot A \cdot T} \\
\mu \mathrm{m} / \mathrm{yr}= & \frac{87600 \cdot W}{D \cdot A \cdot T} \\
\text { di mana, } \mathrm{W}=\text { massa yang hilang akibat } & \text { terkorosi }(\mathrm{mg}) ; \\
\mathrm{D}= & \text { rapat massa }\left(\mathrm{gr} / \mathrm{cm}^{3}\right) \\
= & 7.8 \mathrm{mgr} / \mathrm{m}^{3} \text { atau } 490 \mathrm{lb} / \mathrm{ft} 3 ; \\
\mathrm{A} & =\text { luas permukaan }\left(\mathrm{in}^{2}\right) ; \\
\mathrm{T} & =\text { lama pengujian }(\mathrm{jam}) .
\end{aligned}
$$

\section{HASIL DAN PEMBAHASAN}

$>$ Immersion test dengan menggunakan $\mathrm{HCl}$ $1,5 \mathrm{M}$ secara kasat mata dapat dilihat spesimen yang dilapisi cat dengan suhu $24^{\circ} \mathrm{C}$ lebih cepat terkorosi. Spesimen tersebut lebih cepat berkarat dan terkikis catnya.

\section{Laju korosi}

\begin{tabular}{ccccc}
5,000 & 2,122 & 1,556 & 1,415 & 1,273 \\
\cline { 2 - 5 } 0,000 & a & b & c & d
\end{tabular}

\section{Gambar 1. Laju korosi material pada Immersion Testdengan HCl 1,5 M}

Gambar 1 memperlihatkan bahwa benda uji a, b, c, d mempunyai laju korosi terbesar 2.122 MPY. Sehingga dapat diambil kesimpulan bahwa material yang diperlakukan dengan suhu rendah mengalami laju korosi yang cukup besar dibandingkan yang lainnya.

Immersion test dengan menggunakan $\mathrm{NaCl}$ secara kasat mata dapat dilihat spesimen tidak banyak perubahan namun ada bagian-bagian spesimen yang terlihat bereaksi dan membentuk pola pada spesimen.

Laju korosi

\begin{tabular}{rrrrr}
20,000 & 12,380 & 7,783 & 4,245 & 1,768 \\
\hline 0,000 & a & b & $c$ & d
\end{tabular}

Gambar 2. Laju korosi material pada Immersion Test dengan NaCl. 
Ketahanan korosi terhadap larutan garam yang disemprotkan pada pelat yang dilapisi cat dianalisa dengan membandingkan material pelat satu dengan pelat lainnya yang telah diberi perlakuan berbeda-beda tergantung suhu dan waktu tunggu pengecatan. Hasil perhitungan disajikan didalam Gambar 2. Terlihat bahwa spesimen a, b, c, dan d yang merupakan material yang mendapat perlakuan pengecatan mempunyai laju korosi dibawah nilai 20 MPY yang berarti nilai tersebut masih dapat dikatakan baik. Akan tetapi material yang diberi perlakuan pada suhu dan waktu tunggu minim memiliki nilai yang paling besar sehingga memiliki laju korosi yang tinggi dibandingkan dengan yang lainnya.

Pengujian daya lekat cat, kesemua cat menunjukkan daya lekat yang baik terhadap pelat yang dilindunginya. Namun cat dengan suhu $24^{\circ}$ dan waktu tunggu pelapisan 1 jam kurang baik daya lekatnya. Untuk cat dengan suhu $24^{0}$ dan waktu tunggu pelapisan 1 jam kerusakan catnya hingga 30\%.

\section{KESIMPULAN}

$>$ Material yang dicat dalam keadaan suhu rendah $\left(24^{0}\right)$ dan waktu tunggu pelapisan 1 jam pada pengujian immersion test larutan $\mathrm{HCl}$ 1,5M memiliki laju korosi lebih tinggi dibandingkan dengan suhu dan waktu tunggu yang lain.

$>$ Material yang dicat dalam keadan suhu rendah $\left(24^{0}\right)$ dan waktu tunggu pelapisan 1 jam pada pengujian penyemprotan garam memiliki laju korosi lebih tinggi dibandingkan dengan suhu dan waktu tunggu yang lain.

$>$ Semakin tinggi suhu yang digunakan dan semakin lama waktu tunggu pelapisan pada proses pengecatan maka hasil yang diperoleh semakin baik, laju korosi akan semakin kecil sehingga kapal tidak cepat mengalami perkaratan.

\section{DAFTAR PUSTAKA}

Anonim, 2004. Standard Practice for Laboratory Immersion Corrosion Testing of Metal. United States of America: ASTM G31-72.

Bayuseno, A.P. 2009. Analisa Laju Korosi pada Baja untuk Material Kapal dengan dan Tanpa Perlindungan Cat. Jurnal Rotasi Vol. 11, No. 3

Fontana, and Mars Guy. 1987. Corrosion Engineering. International edition. Mc. Graw Hill Inc.

Kenneth R. Trethewey, and John Chamberlain. 1991. Korosi untuk Mahasiswa dan Rekayasawan. Terjemahan Alex Tri Kantjono Widodo. PT. Gramedia Pustaka Utama. Jakarta

Van Vlack, and H. Lawrence. 1994. Ilmu dan Teknologi Bahan (Ilmu Baja dan Bukan Baja., 5th ed. PT. Erlangga

Zdunek, A.D., et al. 1995. Inspection and Evaluation of Protective Coatings by Visual Imaging Techniques. Northwestern University 